\title{
RADIOCARBON DATING AND TEPHROCHRONOLOGY IN KAMCHATKA
}

\author{
O. A. BRAITSEVA, ${ }^{1}$ L. D. SULERZHITSKY, ${ }^{2}$ S. N. LITASOVA, ${ }^{1}$ I. V. MELEKESTSE ${ }^{1}$
and V. V. PONOMAREVA
}

ABSTRACT. We discuss results of ${ }^{14} \mathrm{C}$ dates obtained from areas of young volcanoes in Kamchatka. We apply these dates
to reconstructing regional volcanic activity during the Holocene.

\section{INTRODUCTION}

Five hundred radiocarbon-dated samples from sections of soil, peat logs and sediments buried by volcanic eruptions were analyzed. The primary objectives of these tephrochronological investigations in Kamchatka are the reconstruction of the formation and dynamics of volcanoes and the identification of tephra marker beds that document important eruptions. ${ }^{14} \mathrm{C}$ dating correlates volcanic events with a time-stratigraphic scale. The majority of dates were determined on buried soils because it is the most widespread material suitable for dating in Kamchatka. We used the following criteria to test the validity of these dates: 1) normal sequence in a soil-pyroclastic section; 2) lack of significant age deviations in double samples of soil; and 3) agreement of dating results obtained for different materials, such as buried soils, peat, wood and charcoal. There were practically no significant deviations of ${ }^{14} \mathrm{C}$ ages resulting from volcanic activity except for that of coal from pyroclastic flows and surges. ${ }^{14} \mathrm{C}$ ages of tephra marker beds from sections separated by
great distances were analyzed several times.

We used the data obtained to determine the ages of active volcanoes of Kurile-Kamchatka and to reconstruct activity patterns, including the timing of volcanic cycles and the formation of volcanic cones. Dates were obtained for most of the major eruptions of Kamchatkan volcanoes that occurred during the Holocene.

Figure 1 shows the "sandwich" structure soil-pyroclastic material that consists of alternating tephra beds interbedded with eolian sandy loams (redeposited pyroclastics and terrigenous materials) and humic buried soils. The soil-pyroclastic sequences formed during the last $12 \mathrm{ka}$, and range in thickness from 3.5 to $15 \mathrm{~m}$. Most pre-Holocene sediments in Kamchatka were denuded by powerful glaciation during the Late Pleistocene.

\section{METHODS}

We dated volcanic events by analyzing organic material from under, above and within the volcanic layer. The best material for dating is buried soil. Each section contains ca. 10-20 layers of humic soil; each layer is $c a .1-5 \mathrm{~cm}$ thick. The organic material from these layers is good for ${ }^{14} \mathrm{C}$ dating because of the short formation period of each soil layer and conservation by pyroclastics. However, in the case of a long-dormant neighboring volcano, soil formation may last 1-1.5 ka, and its thickness may increase to $c a .15-20 \mathrm{~cm}$. We obtained dates for these soils by sampling each layer.

Extracts of minimum and maximum age (Fig. 1) can be considered close to the beginning and end, respectively, of soil formation. In some cases, dates of individual extracts have similar values, which indicate rapid formation of soil interbed. The dates of rapidly forming interbeds and younger

\footnotetext{
${ }^{1}$ Institute of Volcanology, Bul Piipa 9, Petropavlovsk-Kamchatsky 683006 Russia

${ }^{2}$ Geological Institute, Pyzhevsky 7, Moscow 109017 Russia
} 


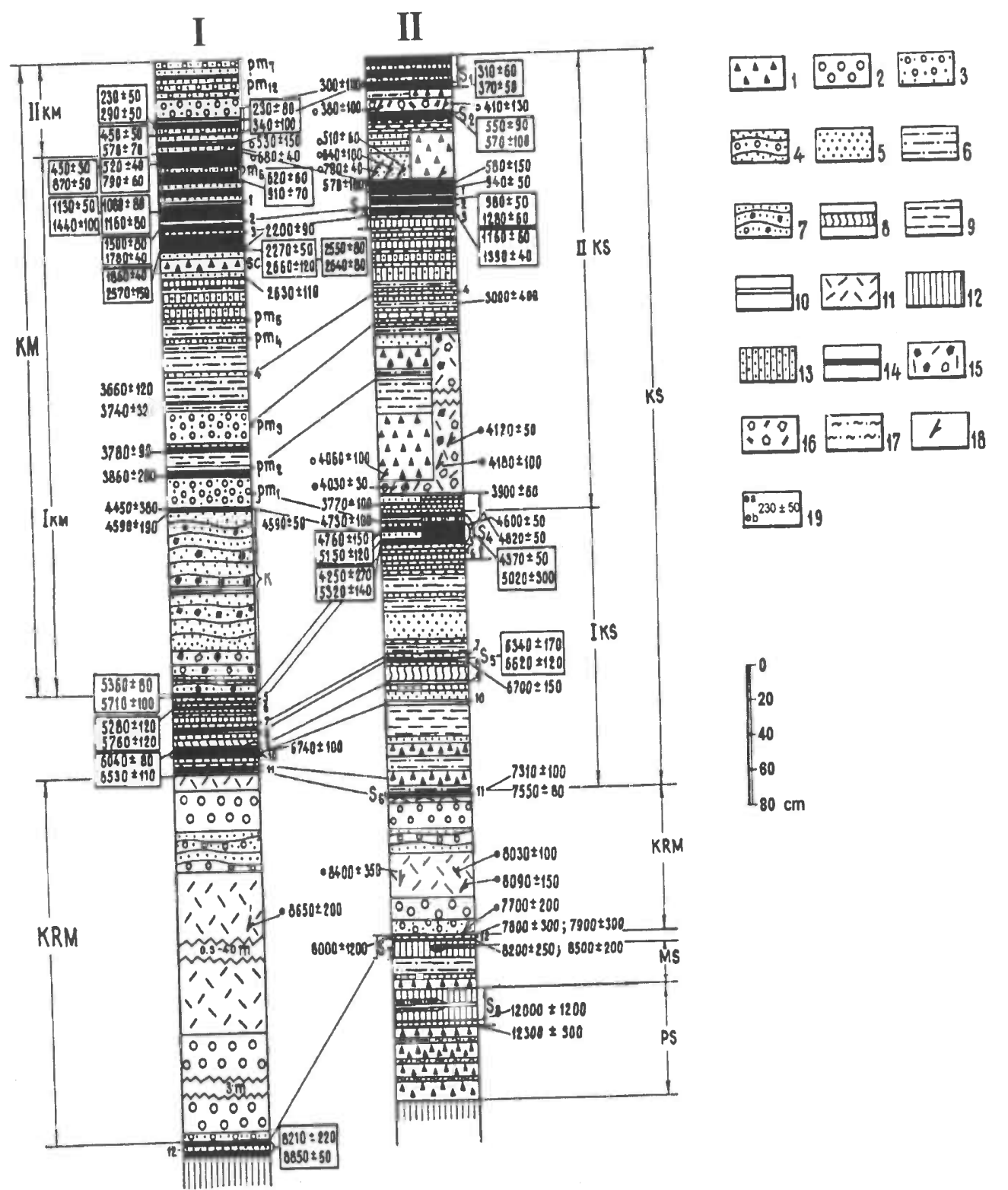

Fig. 1. Summary sections of sediments in pyroclastic covers at the foot of Karymsky (I) and Maly Semyachik (II) volcanoes: 1. volcanic bomb, lapilli, slag gravel; 2. volcanic bomb, lapilli, pumiceous gravel; 3. pumiceous lapilli and coarse ash; 4. stratified pumiceous tephra: lapilli, coarse ash; 5. coarse ash; 6. stratified coarse ash; 7. stratified coarse ash with bomb, lapilli, resurgent material (pyroclastics of primary eruptions of Karymsky); 8. ocherous bed-oxidized gray and yellow coarse ash; 9. thin layers of fine and coarse ash; 10. fine ash; 11. sediment of pyroclastic flows and surges of caldera-forming eruption of Karymsky; 12. sandy loam; 13. sandy loam with admixtures of coarse ash; 14. buried soil; 15. sediment of pyroclastic flow of Maly Semyachik; 16. explosive sediment; 17 . redeposited coarse ash; 18 . wood; $19 .{ }^{14} \mathrm{C}$ dates: $a=$ coal; $b=$ wood; the others = buried soil; KRM = sediments associated with caldera-forming eruptions of Karymsky; $\mathrm{KM}=$ Karymsky sediments. Sediments of Maly Semyachik cones: $\mathrm{PS}=$ Paleo-Semyachik; $\mathrm{MS}=$ Meso Semyachik; KS = Kaino-Semyachik. IKM, IIKM, IKS, IIKS = sediments of large cycles of activity of Karymsky and Kaino-Semyachik. Tephra marker beds: $\mathrm{pm}_{1}-\mathrm{pm}_{12}=$ pumiceous tephra beds of Karymsky; $\mathrm{K}=$ pyroclastics of primary eruptions of Karymsky; $\mathrm{SC}=$ slag interbed of Karymsky; 1-12 transit ash interbed: $\mathrm{S}_{1}-\mathrm{S}_{8}$ buried soil in Maly Semyachik section. 
alkaline extracts from these soils are close to those of overlying pyroclastics. At the same time, underlying pyroclastics may be much older than the soil, because the onset of soil formation may be delayed. This is due to the lower propagation rate of vegetation over the fresh pyroclastics, which is dependent on its initial composition, thickness and overlying area.

Peat-like layers and peat bogs provide another good source of material for dating. Often located far from volcanoes, peat bogs contain ashes that do not affect the rate of peat accumulation. Peat can be dated using both alkaline extracts and cellulose.

Along with charcoal, wood is considered the best dating material. However, in dating volcanic deposits, one should consider the following. Tree trunks or limbs may intersect interbedded narrow layers of tephra. Trees injured by volcanoes may remain standing for $>0.1 \mathrm{ka}$, and after they fall, are buried in younger pyroclastics. Wood often introduces uncertainty in its age, sometimes exceeding $0.2 \mathrm{ka}$. However, thin branches enmeshed in tephra layers are considered good dating material because of their young age and distinct location in the section.

Although considered the best dating material, charcoal presented interpretive problems. Charcoal is scarce in soil-pyroclastic covers because of the low temperature of falling tephra; it is observed mostly in sediments of surges and pyroclastic flows "wedging" into the section. Charcoal underlying lava flows is practically nonexistent in Kamchatka. A possible reason is that, in most cases, the base of Holocene lava flows has not eroded, and older flows were issued during Late Pleistocene glaciation when there was no vegetation. Another explanation may be that organic materials of lava-flow underlayers were burned away, given the high temperature and available oxygen of the flow.

We measured ${ }^{14} \mathrm{C}$ by liquid scintillation counting of benzene. Our technique differs from the more conventional benzene-production process in that lithium carbide is produced by reacting the pretreated samples directly with lithium, rather than combusting the samples to $\mathrm{CO}_{2}$ and reacting the $\mathrm{CO}_{2}$ with lithium. Consequently, many of our samples had low yields of poor-quality benzene, which resulted in poor reproducibility of results. Modified pretreatment (boiling in $\mathrm{HCl}, \mathrm{HNO}_{3}$ and sometimes HF) of the samples improved benzene yields and reproducibility of results.

\section{RESULTS AND DISCUSSION}

The dates obtained from buried soils demonstrated normal sequences and lack of inversions (Fig. 1); from these, we infer that the dates are valid and close to real ages (Braitseva et al. 1988). This is supported by good convergence of dates, which derived from soil samples from several sections. This can be seen clearly in series of dates obtained at the foot of the Karymsky volcano (soil bed between transit ash 3 and the scoria bed) and in the Maly Semyachik section (soils 4, 6, 7) (Fig. 1). We also noted that in several sequential strata of thick soils the dates of the youngest extracts of lower beds were often older than the oldest extracts of the upper beds. This is illustrated in the lower part of soils 3 and 4 in the Maly Semyachik and Karymsky cores (Fig. 1): the upper part (above and below layer $\mathrm{pm}_{6}$ ) and the bottom (under the $\mathrm{K}$ pyroclastic layer). Apparently, it may be explained by the migration of organic matter, especially when humic layers are divided by thin, infrequent ash layers. This forms a sufficiently thick single packet (Maly Semyachik soils 3, 4; soils top and bottom of tephra section of Karymsky). We suggest that several interbeds of these packets were present as a "single" soil with simultaneous accumulation of humus. We also observe that, in some humic interbeds of these soils, the dates of the oldest extracts are consistently higher for each underlying bed, i.e., the ages of soil beds increase with depth. Generally, wood dates agree with dates of buried soils in which they occur. Some samples of cedar (Pinus pumila) from the same bed range in ages from 100-300 yr (Fig. 1). 
Sulerzhitsky (1976) addressed the problem of possible distortion of ${ }^{14} \mathrm{C}$ ages by volcanic $\mathrm{CO}_{2}$, but dates with no significant deviations correspond to those in natural sequences. Lack of contamination may be explained as follows: samples were collected from sites subject to eolian activity, usually located between two rivers where volcanic $\mathrm{CO}_{2}$ does not accumulate. However, we also obtained dates for charcoal from pyroclastic sediments, which were often older than charcoal from soil underlying the pyroclastics. For example, charcoal from the Karymsky caldera dated to 8.4-8.6 $\mathrm{ka}$ (the underlying bed dated to 7.8-7.9 ka), and charcoal from Kaino-Semyachik dated to 4.12-4.18 ka (the underlying soil was $3.9 \mathrm{ka}$.) Apparently, during carbonization, the wood had captured volcanic carbon from $\mathrm{CO}_{2}$ from a hot, gas-saturated flow, which resulted in "aged" dates. The date for charcoal from cooled lapilli sampled at the base of the caldera ( $7.7 \mathrm{ka})$ is close to the ${ }^{14} \mathrm{C}$ age of the underlying soil bed. In this case, carbonization may have been associated with the subsequent warming by overlying pyroclastic flows and the catalytic effect of sulphuric compounds, when no absorption of volcanic carbon occurs. This is analogous to the caldera-forming eruptions near Kurilsky Lake, where we obtained dates for charcoal and carbonized wood from pyroclastic sediments ranging from 8 to $8.4 \mathrm{ka}$, whereas for buried soil and peat underlying the pyroclastics, the youngest dates were $c a .7 .6-7.8 \mathrm{ka}$.

We observed an inversion of dates in some peat bogs located near thermal springs containing methane and volcanic $\mathrm{CO}_{2}$. Basal deposits in peat bogs of Uzon and Opala calderas, directly affected by thermal waters, yielded dates that were $\sim 1.5$ ka too old.

We check our dates by comparing them with those from the same stratigraphic layers in different areas. Figure 1 shows a correlation between the main tephra marking beds of the pumiceous tephra beds of Karymsky and slags of the Maly Semyachik transit ash interbeds, which are $30 \mathrm{~km}$ apart. We identified tephra interbeds in pits and natural outcrops along the profile between the volcanoes. The most significant correlation was the sequence of ash layers, which differ in color, thickness, and granulometric, chemical and mineralogic composition. Dates for beds of the same stratigraphic position, e.g., buried soils in different sections underlying or overlying the same tephra, as a rule, compare well. Such is the case for the upper part of soil 3 of Maly Semyachik and Karymsky soil, including the $\mathrm{pm}_{6}$ layer, as well as the wood from these beds, soil

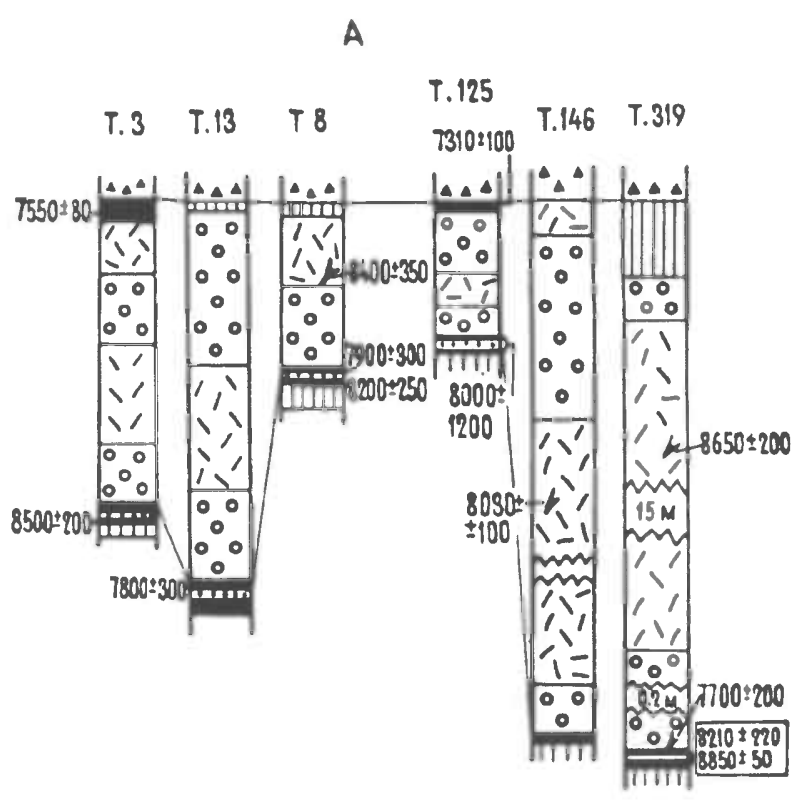

Fig. $2 .{ }^{14} \mathrm{C}$ dates for pyroclastics of the caldera-forming eruption of Karymsky. For legends, see Fig. 1. between transit ashes 1 and 2 , soil under the $\mathrm{pm}_{1}$ tephra bed and soil under the $\mathrm{K}$ layer. Figure 2 shows concurrence of dates obtained for different materials from soils that under- and overlie the pyroclastics of the caldera-forming eruptions of Karymsky. Samples were taken from the bases of Maly Semyachik (T.146) and Karymsky (T.319). 
Figures 3 and 4 show dates from different materials of the largest eruptions of Opala and Ksudach. From the correlation of dates of beds under- and overlying the tephra of Opala, we infer that this eruption occurred 1.4-1.5 ka ago. The tephra dates also agree with the charcoal dates from pyroclastic flows located near the center of the eruption. By dating charcoal and wood from pyroclastics, we concluded that the caldera-forming eruption of Ksudach occurred 1.7-1.8 ka ago. Soil beds underlying the pyroclastics date to $\sim 2-2.2 \mathrm{ka}$, when the soil was forming.

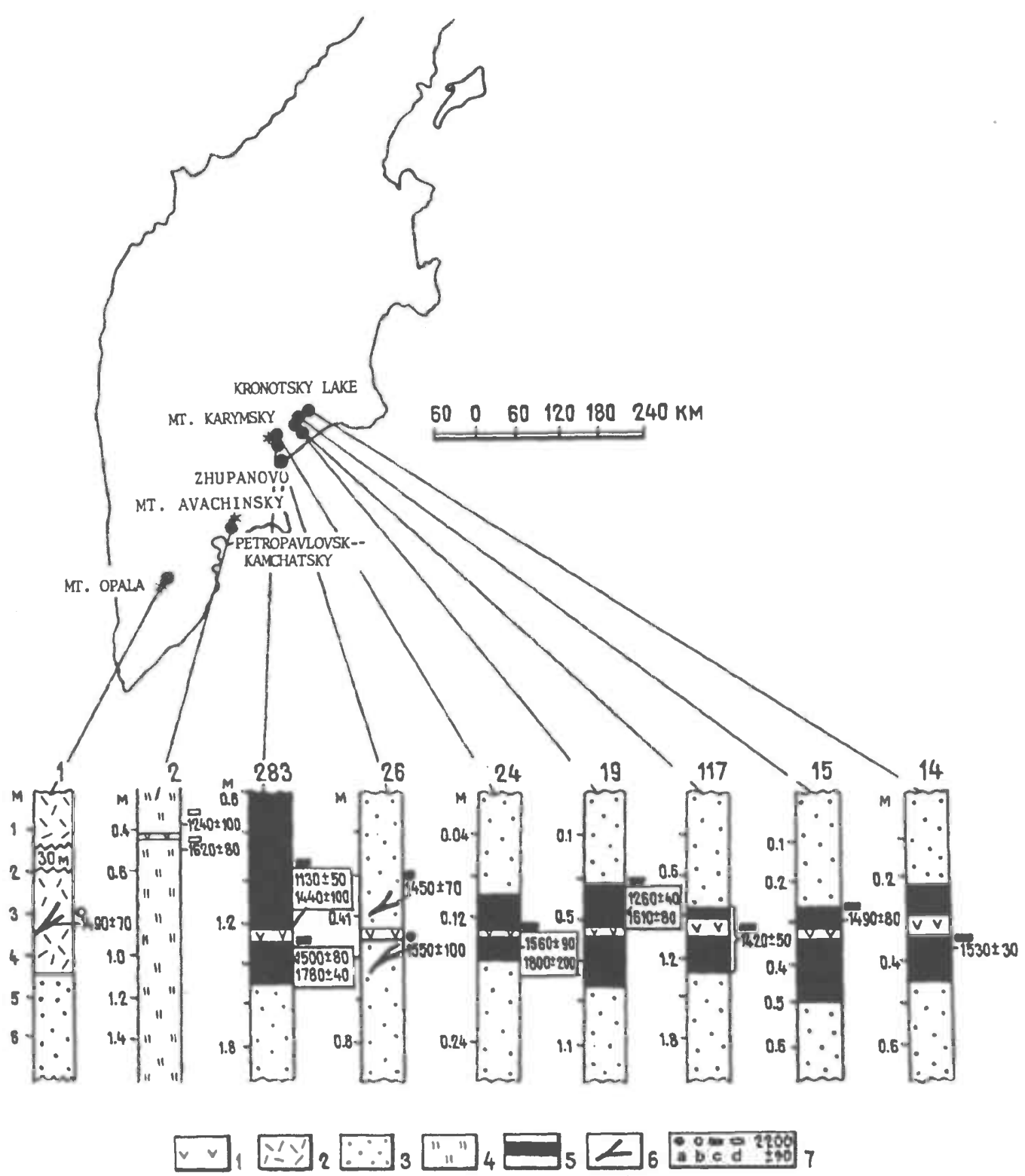

Fig. $3 .{ }^{14} \mathrm{C}$ dates for Opala tephra (1.4-1.5 ka ago): 1. Opala ash; 2. pyroclastic sediments of the Opala eruption; 3 . ash of other volcanoes (without separation in beds); 4. peat; 5. buried soil; 6. charcoal and wood; 7. ${ }^{14} \mathrm{C}$ dates: a. coal, b. wood, c. buried soil, d. peat. Framed dates are from individual extracts of the same soil sample. 


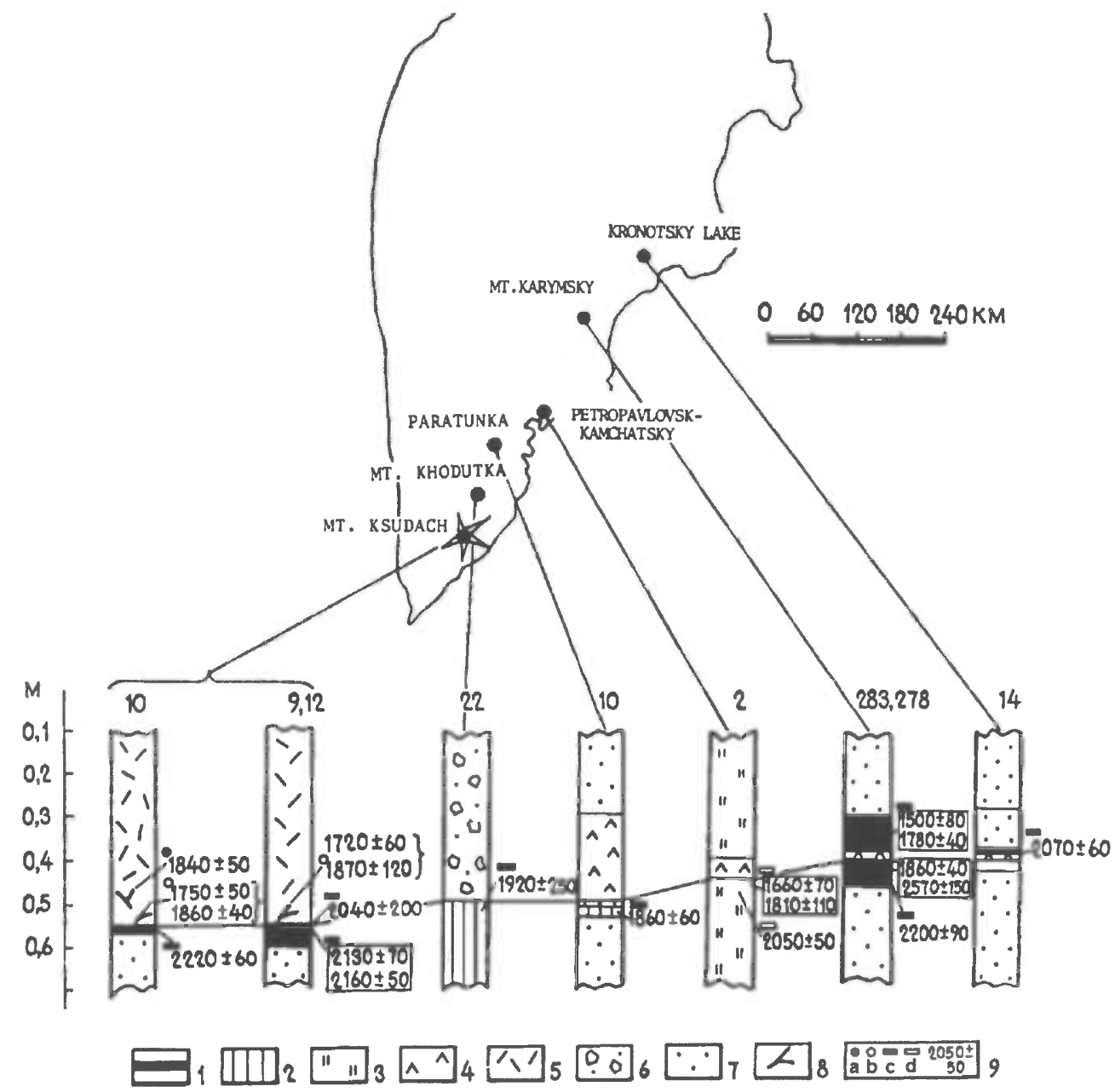

Fig. 4. ${ }^{14} \mathrm{C}$ dates for Ksudach tephra (1.7-1.8 ka ago): 1. buried soils; 2 . sandy loams; 3. peat. Pyroclastics of Ksudach: 4. ash; 5. pyroclastic sediments and 6. pumic lapilli. 7. Ashes of other volcanoes (without separation in beds); 8 . charcoal and wood; $9 .{ }^{14} \mathrm{C}$ dates: a. coal, b. wood, c. buried soil, d. peat. Framed dates are from individual extracts of the same soil sample.

Tephra of the largest caldera-forming eruption of the Holocene, which occurred near Kurilsky Lake, is not only widely distributed in Kamchatka, but is also found in the area of Magadan City $1100 \mathrm{~km}$ from the center of the eruption. The dates for these pyroclastics in buried soils and peat of Kamchatkan sections (7.6-7.8 ka) correpond to dates for peat beds underlying (7.82 ka ago) and overlying (7.67 ka ago) the ash of this eruption in Magadan (Fig. 5). Apparently, this eruption occurred $7.6 \mathrm{ka}$ ago, because, in sections of the eastern volcanic Kamchatkan zone, its ash was found above the pyroclastics of the Karymsky caldera, which dated to $7.7 \mathrm{ka}$ ago. Long-term ${ }^{14} \mathrm{C}$ research on volcanic rocks in Kamchatka has enabled us to date the volcanic events to the Holocene, with a statistical error of 150-200 yr. $\mathrm{Ca}$. $10 \%$ of dates cannot be used for the analysis and further interpretations, for reasons that are not always clear.

Kamchatka ${ }^{14} \mathrm{C}$ ages are uncorrected for changing carbon concentrations in the atmosphere. Results are as follows: 


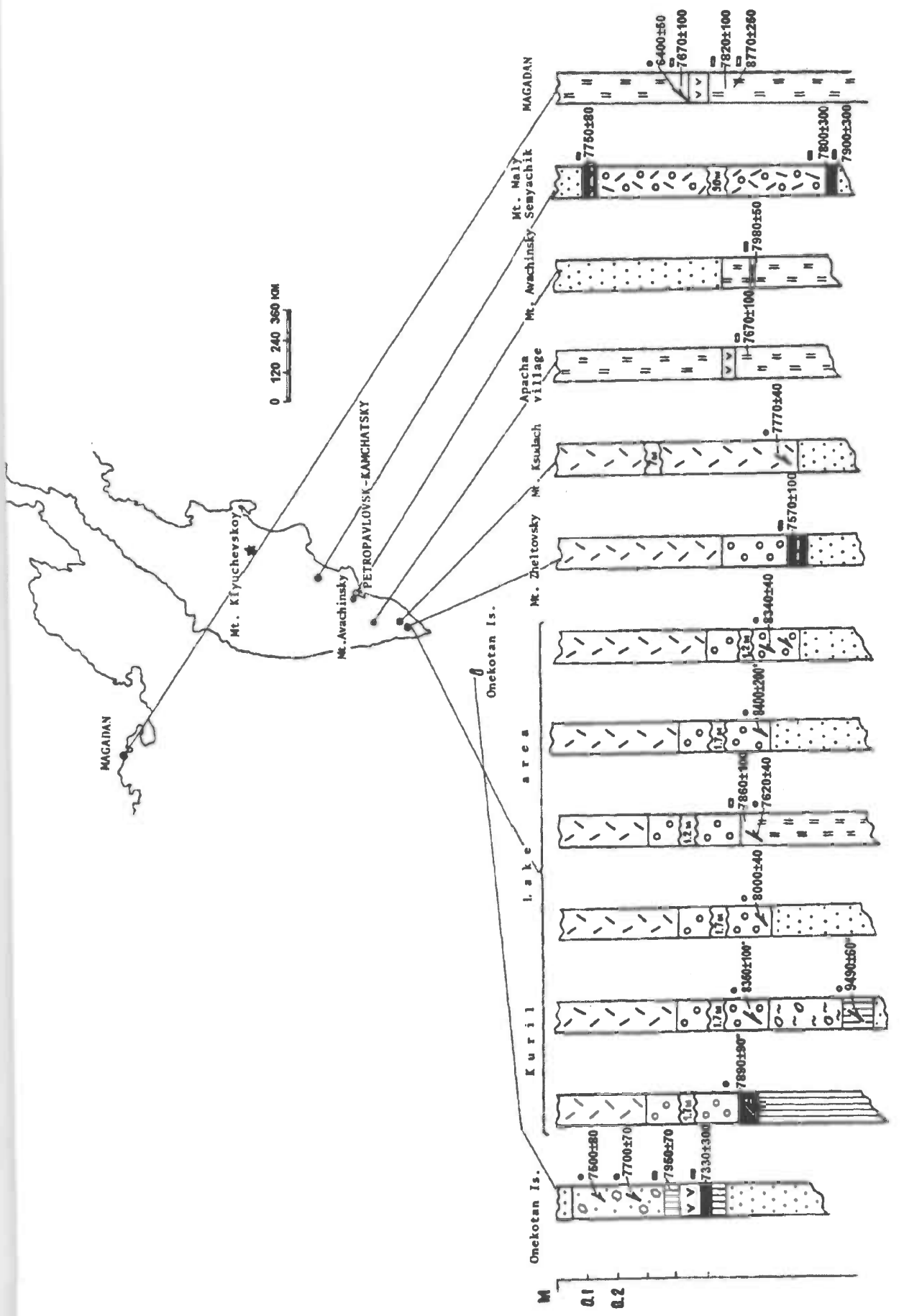

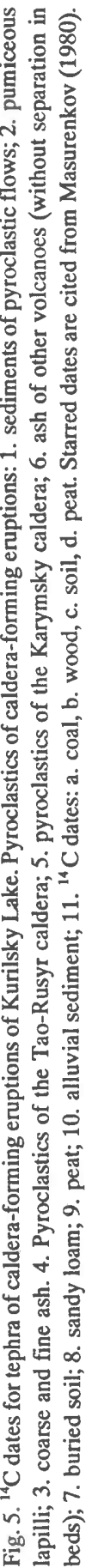


Volcanic eruptions $\quad{ }^{14} \mathrm{C}$ dates

1. Karymsky

2. Maly Semyachik
a. Paleo-Semyachick
b. Mezo-Semyachick
20(?)-11 ka
c. Kaino-Semyachick
$11 \mathrm{ka}$
$7.4 \mathrm{ka}$

formed $\sim 5.3 \mathrm{ka}$ in caldera, which formed $7.7 \mathrm{ka}$

3. Krasheninnikov
a. South cone
b. North cone
c. North inner cone

$11-6.5 \mathrm{ka}$

$5.5-2 \mathrm{ka}$

$1.3 \mathrm{ka}$

4. Molodoi Kikhpinych

a. West cone

b. Savich cone

5. Avachinsky

6. Ksudach

Shtyubel cone

formed during the Middle Holocene

$4.2-4.1 \mathrm{ka}$

$1.4 \mathrm{ka}$

started forming $\sim 3.5 \mathrm{ka}$

$\sim 1.6-1.7 \mathrm{ka}$

From the soil-pyroclastic cover of Klyuchevskoy and Bezymianny, which contains the dated ash marker beds of Shiveluch (Braitseva et al. 1984), these volcanoes formed 4.5-4.7 yr ago and 6.2$6.5 \mathrm{ka}$ ago, respectively.

We also obtained dates for the largest collapsed calderas, formed by strong, explosive eruptions during the Holocene:

Volcanic eruptions $\quad{ }^{14} \mathrm{C}$ dates

1. Karymskaya $7.7 \mathrm{ka}$

2. Kurile Lake caldera $\quad 7.6 \mathrm{ka}$

3. Three young caldera of Ksudach $1.7-1.8 \mathrm{ka} ; 6 \mathrm{ka} ; 8.6-8.7 \mathrm{ka}$

4. Kurile Islands
a. Rusyr
b. Lvinaya Past
$7.5 \mathrm{ka}$
$8.4 \mathrm{ka}$

Dating is only the first step in studying the history and dynamics of volcanic activity. Tephrochronological investigations provide composite stratigraphic sections of pyroclastic sediments that record the sequence of eruptions; their timing is provided by ${ }^{14} \mathrm{C}$ dating. Effusive volcanic products include lava flows and ash beds (Fig. 6). By assigning absolute dates to a stratigraphic section, we derive the sequence and number of eruptions and the timing and composition of erupted products. From the tephra, lava and pyroclastics we can reconstruct the character of the eruptions. This enables us to construct geological maps with calendar ages of volcanic deposits. We can determine the volume of erupted products both for the period of activity and for individual eruptions. Thus, we can show the dynamics of volcanic activity in time, e.g., the time range of active periods, the largest explosive eruptions, issue of lava and pyroclastic flows (Fig. 7), flank eruptions and formation of explosive craters.

During the past $15 \mathrm{yr}$, this method was used to study the formation of active volcanoes in Kamchatka: Karymsky (Braitseva and Melekestsev 1989); Maly Semyachik (Braitseva et al. 1980); Krasheninnikov (Ponomareva 1987; Volynets et al. 1989); Kikhpinych (Braitseva et al. 1990); and the Tolbachinsky zone of slag cones (Braitseva et al. 1981). We are also completing studies of Klyuchevskoy, Shiveluch, Kizimen and Il'insky. 
Our data show that these volcanoes, which formed during the Holocene and continue to grow, have distinct cycles of alternating periods of activity, indicated by volcanic accumulations, and dormant periods, indicated by buried soils. Active periods range from several hundred to several thousand years. We obtained the following values: 1) Krasheninnikov and Maly Semyachik, 1.5-2.1 ka; 2) Bezymanny, 0.4-0.7 ka; 3) Karymsky, 1-1.5 ka. Long dormant periods were noted for: 1) Bezymanny and Krasheninnikov, $\leq 1$ ka; 2) Karymsky and Maly Semyachik, $\leq 2 \mathrm{ka}$; 3) Kikhpinych, $\leq 3.5 \mathrm{ka}$. Even during a $2 \mathrm{ka}$ dormant period, the vent channel of the volcano was not plugged by solidified magma and products deposited onto the surface at the start of the active cycle.

The reconstruction of volcanic history enables us to determine the time of formation of stratovolcanic cones. Many large Holocene stratovolcanoes reached their near-present form in 2$4 \mathrm{ka}$. For instance, the Meso-Semyachik cone of Maly Semyachik formed in $1.5 \mathrm{ka}$; Kaino-Semyachik, $1.6 \mathrm{ka}$; Karymsky, $3.3 \mathrm{ka}$; Savich cone of T'ikhpinych, $1 \mathrm{ka}$. The South and North cones of Krasheninnikov both formed in $4.5 \mathrm{ka}$, but $-80 \%$ of the rocks erupted during the first 1-1.5 ka of activity. Stratovolcanic cones form over a relatively short interval, after which activity decreases sharply and occasional summit or flank eruptions issue magma to lower hypsometric levels. After the dormant period, the volcano regains maximum height in two ways: 1) the channel shifts its strike and a new cone forms near the previous one; 2) as a result of explosion, the summit falls and a crater forms, providing a reserve for completion of the volcano's shape.

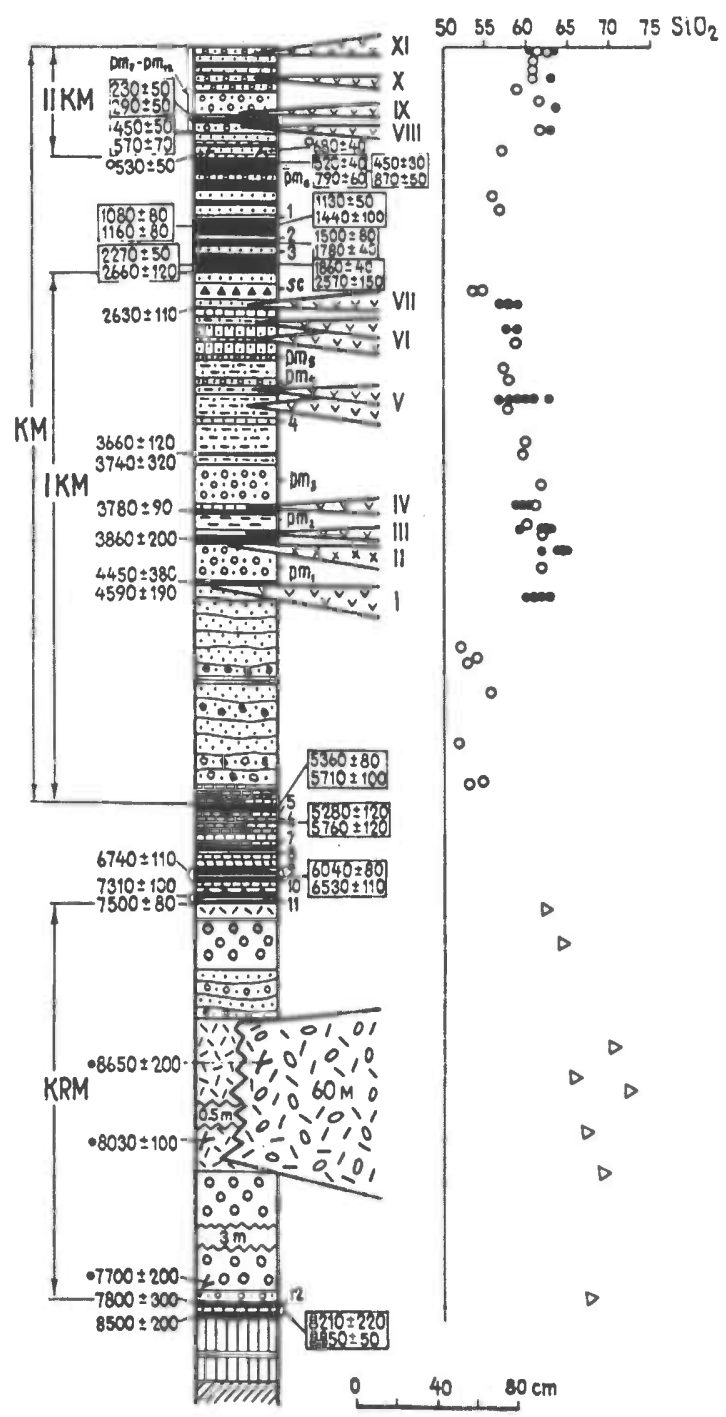

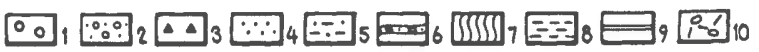 客分1}

Fig. 6. Generalized section of effusive-pyroclastic deposits at the foot of Karymsky volcano: 1 . volcanic pumiceous bomb, lapilli, gravel; 2 . pumiceous lapilli and coarse ash; 3. volcanic slag bomb, lapilli, gravel; 4. coarse ash; 5 . stratified coarse ash; 6 . stratified coarse ash with bomb, lapilli, resurgent material (pyroclastics of primary eruptions of Karymsky volcano); 7. ocherous bed - oxidized gray and yellow coarse ash; 8. thin layers of fine and coarse ash; 9. fine ash; 10. pyroclastic flow deposits of Karymsky caldera-forming eruption; 11. pyroclastic surge deposits of Karymsky caldera-forming eruption; 12 sandy loam; 13. sandy loam with admixture of coarse ash; 14 . buried soil; 15 . base of soil-pyroclastic section; 16 . wood; 17 . andesitic lava flows of Karymsky volcano; 18. dacitic lava flows of Karymsky volcano; $19 . \mathrm{SiO}_{2}$ content in a) tephra and b) lava of Karymsky volcano, and c) pyroclastics of Karymsky caldera-forming eruption; $20 .{ }^{14} \mathrm{C}$ dates: $\mathrm{a}=\mathrm{coal}, \mathrm{b}=$ wood, others = buried soil. I-XI = age groups of the Karymsky lava flows; see Fig. 1 for other indices. 


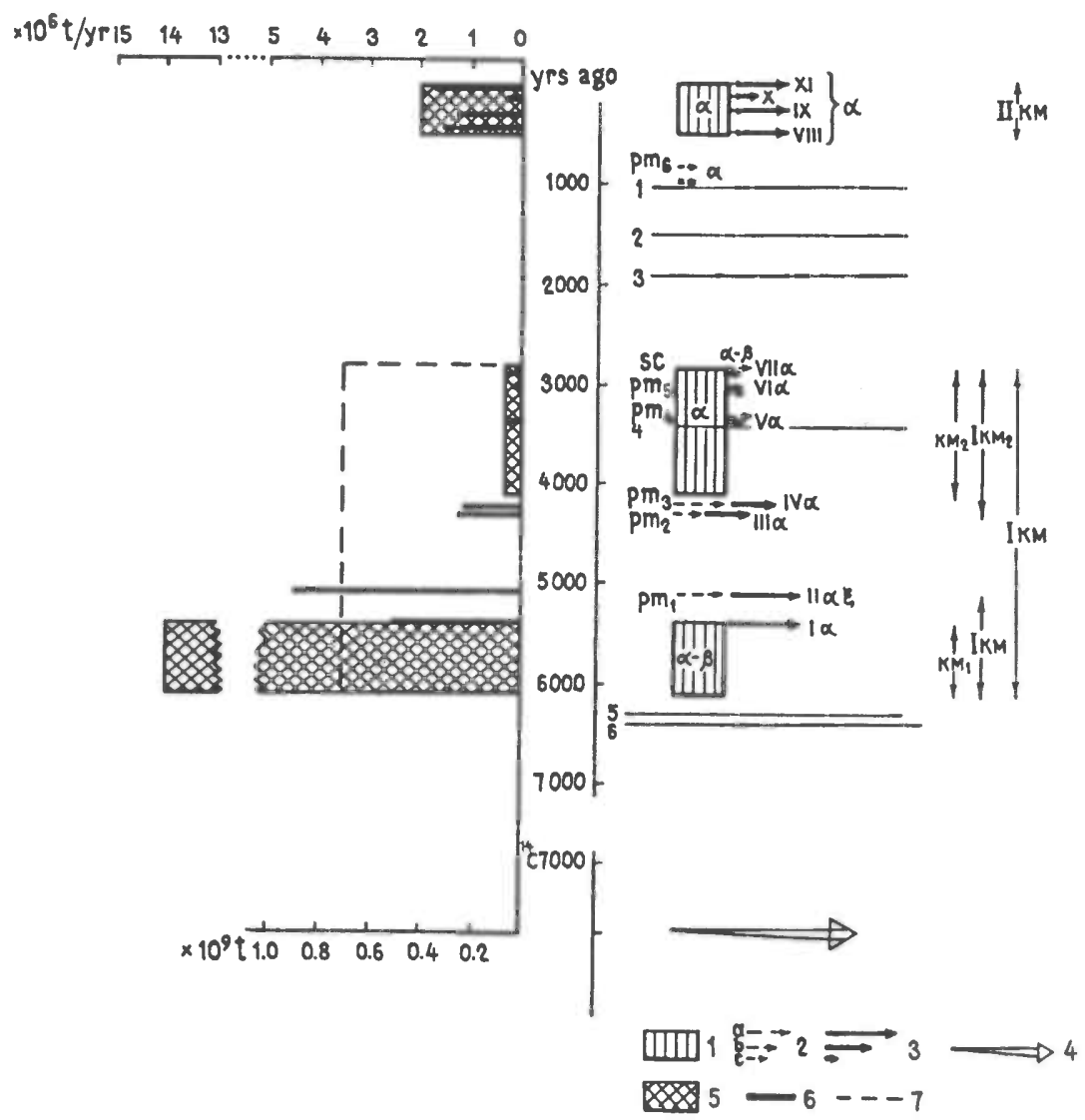

Fig. 7. Dynamics of Karymsky activity: 1 . periods of intense explosive activity; 2 . individual explosive eruptions with volume of erupted material: $a=0.1-0.05 \mathrm{~km}^{3} ; \mathrm{b}=0.05-0.01 \mathrm{~km}^{3}$. $c=0.01-0.001 \mathrm{~km}^{3} ; 3$. series of lava outflows with volume of material: $a=0.5-0.25 \mathrm{~km}^{3}$; $b=0.25-0.05 \mathrm{~km}^{3} ; \mathrm{c}=0.05-0.01 \mathrm{~km}^{3} ; 4$. caldera-forming eruption (without scale); 5 . intensity of material outflow in eruptive phases; 6 . total volume of material of largest eruptions; 7. mean intensity of material outflow during activation of IKM. I-XI = Age groups of lava flows; $\mathrm{pm}_{1}-\mathrm{pm}_{6}, \mathrm{SC}=$ positions of pumiceous and slag interbeds of individual explosive eruptions. IKM, IIKM = periods of activation of volcano; $\mathrm{IKM}_{1} ; \mathrm{IKM}_{2}=$ stages of activity during IKM; $\mathrm{KM}_{1}, \mathrm{KM}_{2}=$ eruptive phases; 1-6 = transit tephra marker beds.

Long periods of activity are not typical of every Holocene volcano. For example, Ksudach, Shiveluch and Kizimen volcanoes discharged energy in short, strong eruptions, separated by quiet periods spanning from $\sim 0.15$ to $2 \mathrm{ka}$. Extrusive domes are sometimes squeezed out during these periods of waning activity, as is the case for Shiveluch. This cyclicity is poorly manifested for the Holocene (Mutnovsky, Koryaksky, Opala, Khodutka), when eruptions were irregular-sometimes very large and spontaneous. In order to distinguish the largest Holocene eruptions in Kamchatka, we have identifed $c a .20$ tephra marker beds. For each, we have determined the stratigraphic position, area of distribution and chemical and mineral composition, and evaluated the volume of material. We ${ }^{14} \mathrm{C}$ dated buried soils and peats under- and overlying tephra, as well as wood and charcoal in them. This enabled us to approximate the ages of eruptions (Table 1). Figures 8 and 9 show the principal directions of ashfalls of the largest Holocene eruptions. 


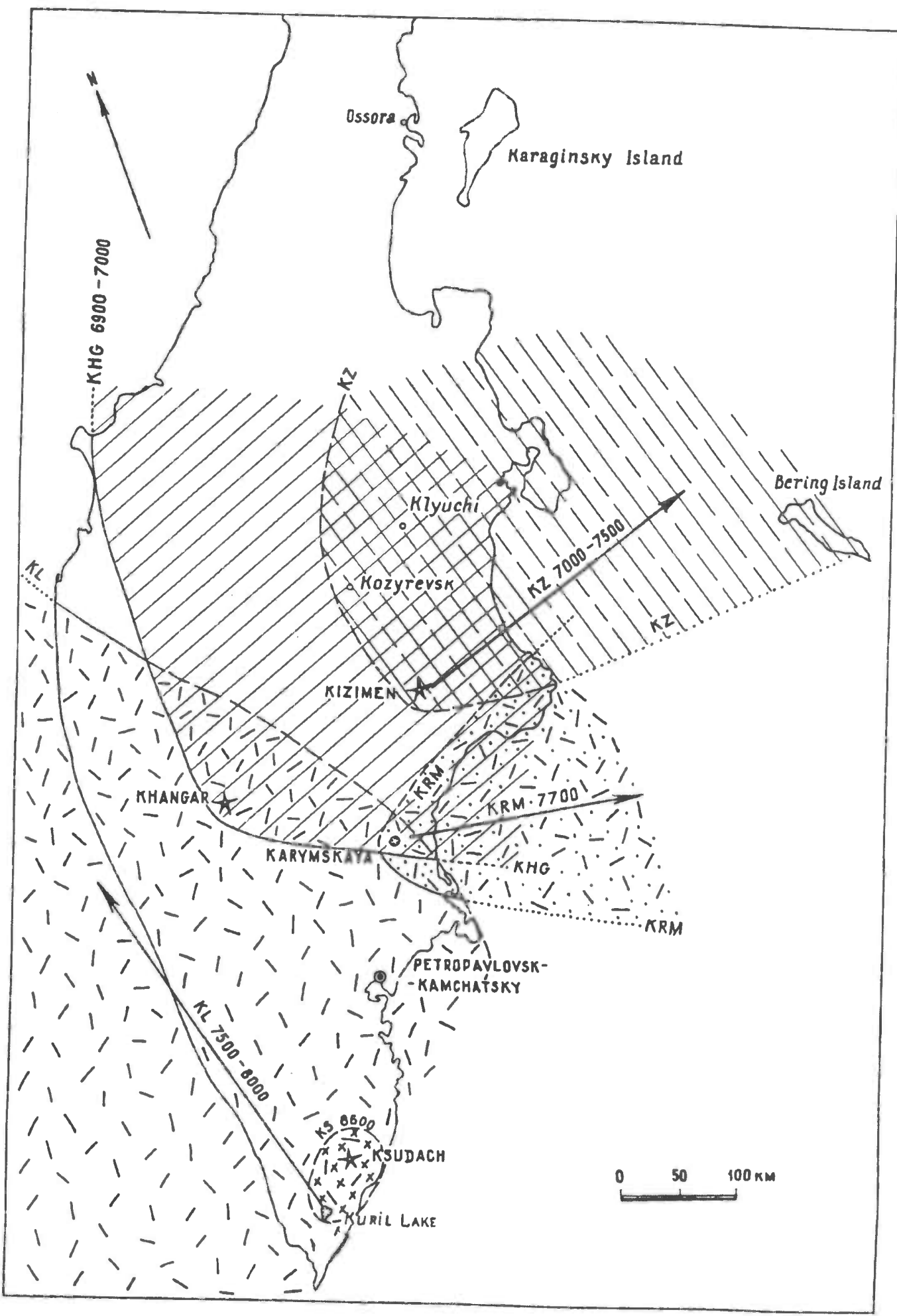

Fig. 8. Main directions of ashfalls for the largest eruptions of Kamchatkan volcanoes during the first half of the Holocene. 


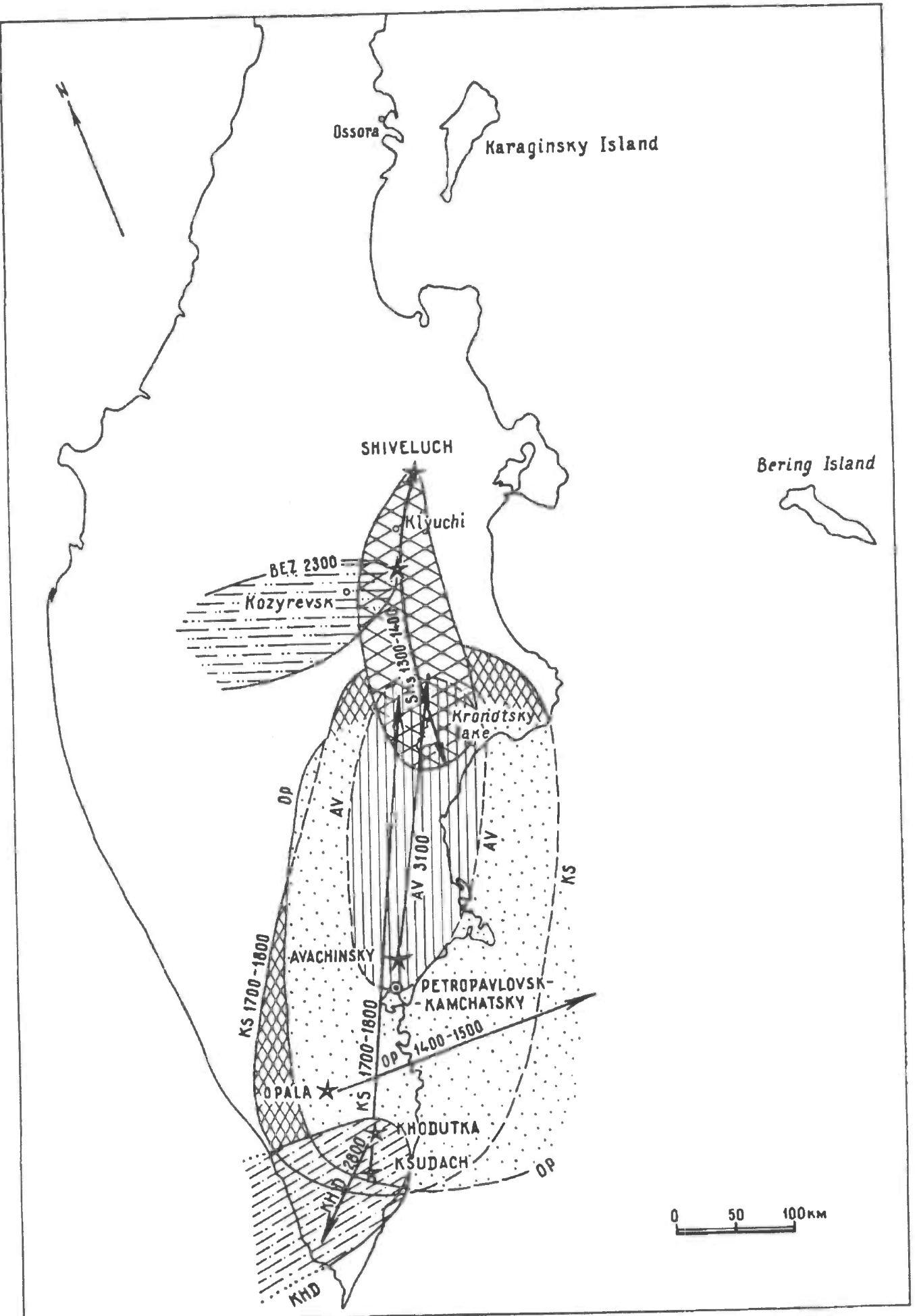

Fig. 9. Main directions of ashfalls for the largest eruptions of Kamchatkan volcanoes during the second half of the Holocene. 
TABLE 1. Principal Tephra Marker Beds of Holocene Eruptions in Kamchatka

\begin{tabular}{llllc}
\hline Eruption center & Index & ${ }^{14} \mathrm{Cage}^{*}$ & Composition** & Volume, $\mathrm{km}^{3}$ \\
\hline Shiveluch & $\mathrm{Sh}_{2}$ & $900-1000$ & $\mathrm{~A}$ & $1.3-1.5$ \\
& $\mathrm{Sh}_{3}$ & $1300-1400$ & $\mathrm{~A}$ & $1.8-2.0$ \\
& $\mathrm{Sh}_{5}$ & 2500 & $\mathrm{~A}$ & -- \\
Avachinsky & $\mathrm{AV}_{1}$ & 3500 & $\mathrm{AB}$ & $2-3$ \\
& $\mathrm{AV}_{2}$ & 5500 & $\mathrm{~A}$ & $0.5-0.6$ \\
& $\mathrm{AV}_{3}$ & 5600 & $\mathrm{AB}$ & $0.6-0.8$ \\
Opala & $\mathrm{OP}$ & $1400-1500$ & $\mathrm{R}$ & $8-10$ \\
Bezymianny & $\mathrm{BZ}$ & $2300-2400$ & $\mathrm{~A}$ & $0.3-0.5$ \\
Khodutka & $\mathrm{KHD}$ & $2800-2900$ & $\mathrm{P}$ & $1-1.5$ \\
Zheltovsky & $\mathrm{ZHT}$ & 5000 & $\mathrm{D}$ & $1.2-1.5$ \\
Khangar & $\mathrm{KHG}$ & $6900-7000$ & $\mathrm{D}$ & $6-7$ \\
Kizimen & $\mathrm{KZ}$ & $7500-7600$ & $\mathrm{D}$ & $2.5-3$ \\
Ksudach & $\mathrm{KS}$ & $1700-1800$ & $\mathrm{D}$ & $7-8$ \\
(calderas) & $\mathrm{KS}$ & 6000 & $\mathrm{~A}$ & $7-8$ \\
& $\mathrm{KS}$ & $8600-8700$ & $\mathrm{~A}$ & 1 \\
Kurilsky Lake, & $\mathrm{KL}_{3}$ & 7600 & $\mathrm{D}$ & $8-10$ \\
caldera & & & & $8-10$ \\
Karymsky caldera & $\mathrm{KRM}$ & 7700 & $\mathrm{D}$ & \\
\hline
\end{tabular}

${ }^{* 14} \mathrm{C}$ dates are rounded off.

${ }^{* *} \mathrm{~A}=$ andesite $; \mathrm{AB}=$ andesite-basalt $; \mathrm{D}=$ dacite $; \mathrm{R}=$ rhyolite

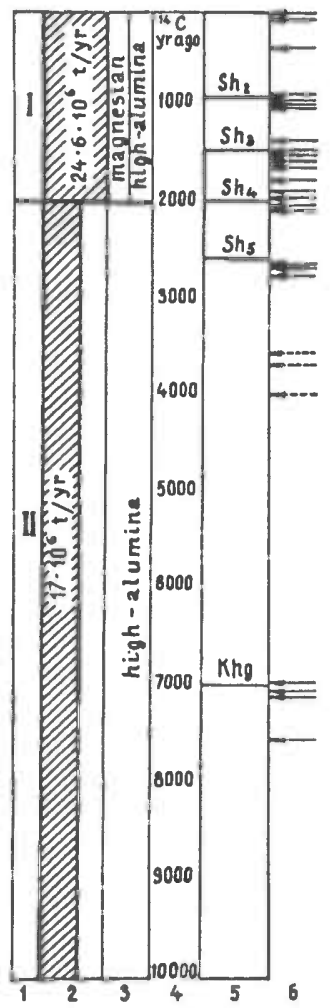

Fig. 10. Sequence of the formation of slag cones in the Tolbachinsky area: 1 . stage of volcanism; 2 . intensity of material outflow; 3. petrographic types of basalts; 4 . time scale; 5. Shiveluch (Sh.) and Khangar (Khg) ash marker beds; 6 . arrows indicate position of slag cones in the Tolbachinsky valley. 
Tephra interbeds are used as distinct datum markers for dating reliefs and sediments. For example, Shiveluch and Khangar ash marker interbeds were used to date volcanics of Tolbachinsky Valley, where the Great Tolbachik Fissure Eruption occurred in 1975-1976. From the relation between lava flows, slags and marker interbeds of overlying ash, we dated the occurrence and sequence of the slag cones (Fig. 10). We constructed a map of Holocene volcanic structures for the area of the Tolbachinsky slag cone which lists the calendar ages of volcanics (Braitseva et al. 1981). The same ash marker interbeds of Shiveluch and Hangar were used for dating periods of activity for Bezymyanny (Braitseva et al. 1990) and for dating a giant failure of Kamen's flank ( $1.2 \mathrm{ka}$ ago) (Melekestsev and Braitseva 1984). Tephra can also be used to date nomad camps buried by lava flows (Braitseva, Litasova and Ponomarenko 1983).

Dating the largest eruptions and studying the dynamics of active volcanoes over a long (10-12 ka) period enables us to understand cyclical volcanic behavior. Thus, we are able to predict long-term volcanic activity and associated hazards (Melekestsev, Braitseva and Ponomarenko 1989).

\section{REFERENCES}

Braitseva, O. A., Egorova, I. A., Sulerzhitsky, L. D., and Nesmachny, I. A. 1980 Maly Semachik volcano. VI. Moscow, Nauka: 199-235.

Braitseva, O. A., Florensky, I. V., Ponomareva, V. V., and Lytasova, S. N. 1985 History of volcanic activity of Kikhpinych in the Holocene. Volcanology and Seismology 6: 3-19.

Braitseva, O. A., Litasova, S. N., Ponomarenko, A. K. 1983 Tephrochronological dating in eastern Kamchatka. Volcanology and Seismology 5: 92-96.

Braitseva, O. A., Litasova, S. N., Sulerzhitsky, L. D., Egorova, I. A. and Grebzdy, E. I. 1989 Radiocarbon dating and palynological studies of soil-pyroclastic cover at the foot of Karymsky and Maly Semyachik volcanoes. Volcanology and Seismology 1: 19-36.

Braitseva, O. A. and Melekestsev, I. V. 1989. Karymsky volcano: History of formation, dynamics of activity and long-term prognosis. Volcanology and Seismology 2: 14-31.

Braitseva, O. A., Melekestsev, I. V., Bogoyavlenskaya, G. E. and Maksimov, A. P. 1990 Bezymanny volcano: History of formation and activity dynamics. Volcanology and Seismology 2: 3-15.

Braitseva, O. A., Melekestsev, I. V., Ponomareva, V. V., Litasova, S. N. and Sulerzhitsky, L. D. 1981 Tephroand geochronological investigations of the Lolbachinsky regional zone of slag cones. Volcanology and Seismology 3: 14-28.

Braitseva, O. A., Sulerzhitsky, L. D., Litasova, S. N. and Grebzdy, E. I. 1984 Radiocarbon dating of Holocene sediments of soil pyroclastic covers of Klyu- chevskoy volcano group. Volcanology and Seismology 2: 110-116.

Masurenkov, Yu. P., ed. 1980 Long-Lived Center of Endogenetic Activity in South Kamchatka. Moscow, Nauka: 171 p.

Melekestsev, I. V. and Braitseva, O. A. 1984 Gigantic failures on volcanoes. Volcanology and Seismology 4: 14-23.

Melekestsev, I. V., Braitseva, O. A. and Ponomareva, V. V. 1987 Activity of Mutnovsky and Gorely volcanoes in the Holocene and volcanic hazards in adjacent regions (based on tephrochronological data). Volcanology and Seismology 3: 3-18.

1989 Prediction of volcanic hazards on the basis of the study of dynamics of volcanic activity, Kamchatka. In Volcanic Hazards. Berlin: Springer-Verlag, 10-35.

Melekestsev, I. V. and Sulerzhitsky, L. D. 1987 Ksudach volcano (Kamchatka): The last 10,000 years. Volcanology and Seismology, 4: 28-39.

Ponomareva, V. V. 1987 Krasheninnikov volcano: history of formation and activity. Volcanology and Seismology 5: 28-44.

Sulerzhitsky, L. D. 1976 Radiocarbon dating of volcanic events. In Current Problems of Geochronology. Moscow: Nauka, 292-300.

Volynets O. N., Ponomareva, V. V. and Tsuryupa, A. A. 1989 Petrological and tephrochronological investigations of Krasheninnikov volcano, Kamchatka. Izvestiya Akademii Nauk SSSR, Seriya Geologicheskaya 7: 15-31. 